\title{
Sun, Sand and Submachine Guns: Tourism in a Militarized Xinjiang, China
}

\author{
Gregory Fayard ${ }^{*}$
}

\begin{abstract}
In recent years, domestic tourism into the Xinjiang region of China has grown rapidly. Government officials view tourism as a source of both economic capital and social stability, presenting a normalcy that makes it attractive for investment. There are two paradoxes to Xinjiang tourism. According to most literature, a massive military presence should deter tourists, but numbers have continued to grow in the militarized Xinjiang region. Second, the cultural "otherness" of Xinjiang is a big draw to the region, yet this culture is being suppressed by state policies to contain Islam. Using a dataset of Han Chinese travel diaries, I look at how narrated tourist experiences of Xinjiang justify policing, how ethnic boundaries are reinforced by practices in both transportation and personal interaction, and how state policies influence Chinese travellers' views on the authenticity of their experience. While bodily assurances of security substantiate political legitimacy, tourists resist the bureaucratic management of sites, allowing for critiques focused almost exclusively on aesthetic taste.
\end{abstract}

Keywords: Xinjiang; China; Belt and Road Initiative; Uyghur nationality; tourism

In recent years, the Xinjiang Uyghur Autonomous Region of China has become a police state. Movements across the region are controlled by a dense network of military police, security cameras, facial scanners, police checkpoints and razor wire. ${ }^{1}$ Public expressions of Islamic faith by Uyghurs, Kazakhs and Hui peoples have been harshly suppressed, and Muslims are now targets of numerous so-called counter-terrorist interventions that seek to constrain their physical mobility and change their thinking, culture and behaviour. ${ }^{2}$ It is estimated that up to 1.5 million Uyghurs and other Muslims have been incarcerated in the Xinjiang region. ${ }^{3}$

Interestingly, at the same time as the region has become intensely militarized, it has also become a popular tourist destination. According to most literature on

* Department of Sociology, University of California, Berkeley, CA, USA. Email: gmfayard@berkeley.edu.

1 Zenz 2018b.

2 Leibold 2020; Anderson and Byler 2019.

3 Zenz 2019. 
travel and security, a region's affiliation with terrorism should deter mass tourism. ${ }^{4}$ Yet while Muslim mobility has been curtailed in the region, ethnic Han tourists have begun to freely explore Xinjiang's newly accessible landscapes and publicly praise its exotic beauty. By looking at tourist practices, this paper seeks to explain why, in spite of the increased military crackdowns and suppression of indigenous ways of life, the tourism industry in Xinjiang has boomed. It demonstrates how tourism is used to build political legitimacy in the region, and how domestic travellers negotiate the recent processes of both ethnic-based securitization and commercial development of tourist sites.

\section{Background on Xinjiang and Xinjiang Tourism}

The story of the heightened militarization in Xinjiang combines both an increasing aversion to and suppression of Islam by the state and new technologies of social control. In response to a string of alleged terrorist attacks, riots and protests by ethnic Uyghurs, the central state has mobilized its security apparatus to pacify the region and ensure complete allegiance. Islam, once considered by state leaders to be a peaceful religion that was occasionally distorted by a minority of extremists, has in recent years become seditious in the eyes of officials. Islamic piety now connotes ethnic separatism and religious extremism. Concordant with this shift in sentiment, the government has instituted a series of physical controls and indoctrination techniques that mark the Islamic element as deviant as well as implementing various purification programmes designed to build loyalty to the Party. Such measures include the removal of the Uyghur language from schooling, shuttering mosques, encouraging the reporting of relatives' religiosity to authorities and the mandatory training of shopkeepers in the arts of resisting terrorist incursion.

Although the north-west frontier has long been used as an experimental ground for new political techniques, ${ }^{5}$ recent digital technologies have allowed for unprecedented surveillance. ${ }^{6}$ Ethnic policies carve up the landscape and sort populations into those considered reliable, i.e. Han Chinese, who move easily across its deserts and grasslands, and those considered unreliable (Uyghurs, Hui and Kazakhs), who are constantly tracked and monitored for seditious movements. A vast network of integrated data relays can theoretically pinpoint one's whereabouts and perceived threat level at any moment. Police regularly request identification and facial scans, and some cities have placed sentry stations at nearly every intersection. Uyghur-owned vehicles in certain areas must be fitted with GPS tracking devices. ${ }^{7}$ Passports are nearly impossible to procure for Uyghurs and other minorities, and foreign contacts in general are grounds for

4 Enders and Sandler 1991; Drakos and Kutan 2003.

5 Millward 1998.

6 Leibold 2020; Mozur 2019.

7 Phillips 2017. 
suspicion. ${ }^{8}$ Uyghurs arriving from abroad are subject to special interrogation and health checks that collect DNA, blood type and other biometrics, information which can be used to monitor future activities. As Darren Byler put it, at present the "the principal purpose of Uyghur life is to generate data."

Officials have also initiated the mass detention of "unreliable elements" in special training centres, where large numbers of Muslims, mainly men, are forced to undergo cultural purification, which involves learning Mandarin, singing patriotic songs, praising Xi Jinping 习近平 and having their previous loyalties eroded by bodily and psychological techniques. ${ }^{10}$ Security spending increased ten-fold from 2007 to 2017, with a 93 per cent increase between 2016 and 2017. ${ }^{11}$ Additionally, thousands of plainclothes Uyghur guards have been hired to patrol streets. $^{12}$

At the same time, the Xinjiang tourism industry is expanding. From 2011 to 2018, total tourist visits increased by 266 per cent, from nearly 40 million to 150 million, although the year-on-year trend was broken by a dip in 2014, the year of a major bombing in Urumqi, the capital of Xinjiang, and the introduction of a "strike hard" (yanda 严打) campaign against violent extremism. ${ }^{13}$ According to People's Daily, to make up for that decline in visitor numbers, the Xinjiang Tourism Bureau launched a scheme in 2014 that offered a 500-yuan subsidy to each visitor to the region. ${ }^{14}$

Communist Party officials view the tourism boom as a sign of the Party's strategic success in economic and social development. State media frequently extols the tourism boom in Xinjiang as evidence of positive changes in social stability, living conditions and ethnic solidarity. ${ }^{15}$ Additionally, the symbolic normalization embodied in the arrival of regular visitors supports the Party's vision of the region as a stable pillar and hub in its Belt and Road Initiative - a place safe for investment. The Xinjiang government has sought to portray the region as a place of "prosperity, civilized progress, unity, and stability," using tourism as an engine of growth for the new Silk Road. ${ }^{16}$

There is no doubt much to attract a visitor to Xinjiang. Once part of the Western Regions ( $x i y u$ 西域) conquered by the Qing Empire in the 18th century, it has long stood apart in mainland eyes as a restive and remarkable place filled with alien ways of life, majestic scenery and valuable natural resources. ${ }^{17}$ Stimulated by improved infrastructure and positive portrayals in such media as

8 Finley 2019; Standish and Toleukhanova 2019.

9 Byler 2019

10 Zenz 2018b; Vanderklippe 2018.

11 Zenz 2018a.

12 Zenz 2018b.

13 Cockerell 2019.

14 Wang, Zhida 2014.

15 Liu 2019; Xu 2018.

16 "Xinjiang weiwuer zizhiqu lüyouye fazhan di shisan ge wunian guihua" (The 13th Five-Year Plan for the development of the tourism industry in Xinjiang). Xinjiangtour, 13 February 2017, http://zw. xinjiangtour.gov.cn/info/1061/53725.htm. Accessed 3 May 2019.

17 Perdue 2005. 
Chinese National Geographic, its landscapes and folkways are contemporary objects of tourist desire. Visitors to Xinjiang form one part of the increasingly important tourism industry in China where the expanding transportation and sanitation infrastructure, rising incomes and the installation of standardized traveller facilities allow multi-day access to most regions. ${ }^{18}$

It should be noted that the vast majority (over 96 per cent) of tourists to Xinjiang are mainland Chinese; foreign tourists are closely monitored and often turned away at various points. Some foreign visitors find they may only be allowed to explore and take pictures of the "positive things," which hints at the existence of less attractive images. ${ }^{19}$

\section{Literature Review and Research Questions}

There are three interconnecting branches of tourism research that can shed some light on the puzzling nature of Xinjiang travel. They are focused on securitization, ethnic relations and authenticity.

Scholars have long noted that pacification of a territory is one of the prerequisites for leisure travel, with perceived risk to life and limb one of the surest deterrents to tourists. ${ }^{20} \mathrm{~A}$ reputation for being the site of terrorist activities has been shown to negatively impact tourist arrivals. ${ }^{21}$ Politicians and businesspeople work hard to frame regions known for recent political turmoil as peaceful and safe areas for travellers. ${ }^{22}$ While some literature addresses "dark tourists" those drawn to places of trauma and danger ${ }^{23}$ - these are usually a minority of thrill-seekers. In Xinjiang, tourism is a mass phenomenon, with many of its destinations pre-packaged in the same way as more ordinary tourism destinations. Although tourism to Xinjiang is undoubtedly negatively correlated with recent violence, the "forces of repression" - the police and its weaponry - do not seem to have the same deterrent effect that we would expect according to the literature. This raises the key research question: what role do tourists play in the pacification of spaces?

Another body of literature addresses ethnic relations in tourism, showing for example how ethnic groups on the Kenyan coast mobilize cooperatively and competitively against threats to tourism, ${ }^{24}$ how minorities in China dramatize culture to attain capital, ${ }^{25}$ and how racial relations are sustained by backstage and frontstage performances to foreigners in Cuba. ${ }^{26}$ Typically, these works presume a durable host community with some strategic choice in the cultural

18 Airey and Chong 2010.

19 Martin 2019.

20 Richter 1980; Hall, Timothy and Duval 2004.

21 Enders and Sandler 1991; Drakos and Kutan 2003; Saha and Yap 2014.

22 Lepp and Harris 2008; Rivera 2008.

23 Lennon and Foley 2000.

24 Jamison 1999.

25 Oakes 1997.

26 Sanchez and Adams 2008. 
deployment of its most marketable face. Yet the ethnic project that operates in Xinjiang is much closer to cultural erasure in which open displays of Islamic culture lead to persecution. The ethnic tourism - that is tourism concentrating on experiencing peoples with putatively unique cultural identities ${ }^{27}$ - in Xinjiang is qualitatively different than that typically studied by scholars. Many Uyghur religious practices are now considered to be radical and antithetical to Chinese norms. Islam has been metaphorically described as a "virus" and a "cancer" by internal Party documents. ${ }^{28}$ To officials, Uyghur culture is something that must be cleansed, even as it beckons tourists with its distinctiveness. This raises another key research question: how does tourism affect ethnic boundaries in a militarized, apartheid context?

A third area of research directly addresses Chinese domestic tourism and asks whether Chinese tourists meet Western standards for an exploratory tourism that searches for authenticity. Pál Nyíri's original work on "scenic spots," defined as those state-sanctioned spaces of visitation that abrogate the need for adventuring, has triggered a debate over the essence of Chinese travel. ${ }^{29}$ Do Chinese tourists adhere to a "stop-photo-sleep" model of movement or something more akin to a Lonely Planet-style attempt to get beyond facades? ${ }^{30}$

Answers to this question could be greatly supplemented by an investigation of Xinjiang, where the spatial scale, mode of travel (the automobile) and ethnic composition shape tourist expectations in ways inconsistent with other major destinations. In addition, security measures put in place to keep travellers safe permeate into the demand side of a site. The technostructure of security, while giving Han travellers a sense of ownership and belonging, might also deprive the local scene of the sincere public expression of cultural content that makes for satisfied viewing. Cultural tourism might thus be compromised by the repressive forces. Another important research area then is to examine how tourists psychologically navigate the militarized, contested terrains of Xinjiang in terms of desired authenticity.

While the study of Xinjiang tourism addresses these fundamental questions, it also raises more. What role does tourism play in the formation of Han Chinese political consciousness? How do Han tourists interpret and make sense of encounters with the police regime of Xinjiang? A few journalists and foreign writers have written of their own movements within Xinjiang, but we know little about the subjective experiences of Chinese themselves, particularly how they assess the region's securitization and system of mobility controls.

\section{Data and Methods}

This study draws on novel materials which have not previously been used to investigate contemporary Xinjiang. Owing to the relative inaccessibility of

30 Chio 2014; Kolas 2008; Shepherd 2009. 
Xinjiang to outside researchers, scholarly knowledge of its situation has been difficult to generate and fraught with ethical concerns. Travelogues are one means to produce new insights on the ongoing sociopolitical processes of this important region.

Data for this paper are mainly drawn from four online sources. The first is a sample of 45 travel diaries, written in Mandarin, by Han Chinese who visited Xinjiang between 2010 and 2019. The majority (31 of 45) of these diaries appeared between 2017 and 2019, a period when re-education camps were being used to detain large numbers of Muslims. The diaries were written mainly by educated urban Chinese and posted online to public blog pages, online travel sites or automobile enthusiast sites. Most were created by mainland Chinese, although I include two by Taiwanese travellers. The average text length of the diaries is about 13,800 characters, and most contain hundreds of photographs. Almost all (approximately 87 per cent) of the diarists travelled by automobile, although four mainly travelled by train and two used buses.

In order to compare ethnic relations, I rely on a second dataset of travel diaries by Han Chinese tourists travelling to Tibetan regions (22 diaries written between 2006 and 2018). I use these travelogues mainly to compare Han-Tibetan interactions with ethnic interactions in Xinjiang.

According to a survey of outgoing tourists, those who write travel diaries tend to be well-educated (having tertiary education) and middle-class. Their most significant motivations for publishing travelogues are documenting and sharing their trips and the subjective enjoyment of blogging. ${ }^{31}$ Those who read and follow content on travel sites state their primary reasons are to help them plan their own travel itineraries, plot routes, ascertain the major sites and learn about food recommendations. ${ }^{32}$ In the current dataset, the majority of the diarists who travelled to Xinjiang hail from China's largest cities, including Beijing (12 trips), Shanghai (4), Guangzhou (3), Urumqi (3), Nanjing (2), Shenzhen (2) and Xi'an (2). Many are car owners and so are likely to be fairly affluent, given that Ministry of Public Security statistics show that as of the beginning of 2019, only about 240 million Chinese owned vehicles, or about 25 per cent of the population aged 25 or above.

The third data source comprises online reviews taken from travel booking sites for major Xinjiang attractions. These reviews are used mainly to substantiate public opinion on certain destinations. Finally, where relevant, I examine official media, government reports, magazine articles and online automobile advertisements relevant to Xinjiang travel.

I performed content analysis on these travel materials, using an iterative approach that combines both deductive and inductive analysis. Deductively, in keeping with the literature review above and major research questions, I focused a priori on classifying themes that relate to security and safety, state-building 
(such as infrastructure, law enforcement, territorial marking and historical interpretations), ethnic relationships, cultural authenticity and feelings of exploration. Inductively, I recorded emerging insights, revising my conceptual frames and re-assessing my dataset based on these patterns. In particular, greater attention was given to the affective elements as my theoretical constructs do not address these. After adapting the categories to fit the data, I looked for thematic closure where a preponderance of evidence suggested recurring, consistent reactions to certain situations. Exceptions were noted, but these widely shared patterns formed the basis of my analysis.

\section{Results}

\section{Background imagination on Xinjiang}

In tourism, the narrative arrives before the traveller. This is particularly true in China, where numerous thousand-year-old sites thrive in collective memory in novels, textbooks, news programmes, movies and guidebooks. This also applies to Xinjiang in part. For example, Journey to the West (Xiyouji 西游记), the novel tracing the monk Xuanzang's 玄牀 numerous travails to retrieve sutras from India, is constantly referenced by travellers. Compared to other regions of China, however, travel to Xinjiang is still embryonic and narratives are still being developed. Furthermore, many sites have yet to be formally included as scenic sites, so there are no entrance gates and fees.

Xinjiang offers tourists a huge space to explore. In the Taklamakan Desert, for example, drivers can randomly park on the side of the road and trudge up and down sand dunes. What gratifies many travellers about this kind of undemarcated space is its lack of artificiality. One female visitor to Xiata Canyon (Xiata xiagu 夏塔峡谷) draws analogies to entering a foreign national park where the original ecology is retained. ${ }^{33}$

The main means of travel in Xinjiang is by motor vehicle (either personal vehicle, rental car or hired driver), so that one architect of the imaginative consumption of spaces is automobile advertising. While advertisements do not automatically express the belief systems of consumers, marketing materials do speak to psychological impulses of empowerment and finding the self. ${ }^{34}$ Of those who drove their own vehicles and I could determine the type of vehicle, 64 per cent travelled in sport utility vehicles.

While few if any marketing materials mention Xinjiang specifically, many feature the isolated landscapes found in frontier regions like Tibet and Xinjiang. One Nissan Navara advertisement on xcar.com in September 2018 shows a large SUV splashing off-road through water (something drivers attempt in

33 Tekes (Tekesi 特克斯), 2018. To anonymize sources, I use the key destination and year to indicate which travel diary is referenced.

34 Frank 1997; Popp 2012. 
Xinjiang) with the tagline: "wherever you want to go, there's no place you cannot reach." In another advertisement, for the BMW X5 in autohome.com in February 2019, a white SUV is parked in front of an unmarked glacier in the Kashgar (Kashi 喀什) region), instructing viewers to "break a thousand boundaries, establish new boundaries” ( $p o$ wanjing, li xinjing 破万境, 立新境). Thus, there is a prefabricated notion of automobility, particularly among SUV drivers, that one will not follow prefabricated notions. While Xinjiang tourists are by no means patternless in their movements, they interact with a consumer ethos that suggests they travel off the beaten path.

\section{Preparing for a Xinjiang trip}

There are many online travel guides that advise on when to visit Xinjiang, where to go and how to get around. A widely viewed introductory article on the website Mafengwo describes Xinjiang as being China's largest province (shengfen 省份), bordered by six countries and marked by remoteness and mystery (shenmi 神秘). ${ }^{35}$ Although Xinjiang is administered at a provincial level and many of the diarists consider it to be a province, it is technically an autonomous region, or zizhiqu 自治区. In general, Xinjiang vacations tend to cover large swaths of latitude and longitude and advice tends to centre on dealing with the great distances away from the normal, comfortable routines of mainland China.

Most guides recommend packing dried food because of the great distances between places of re-supply. They suggest filling luggage with both warm and cold weather clothes, as the temperature changes rapidly. However, the most important item to bring is an official identification card, which is necessary not only to cross security checkpoints but also to accomplish mundane tasks such as re-fueling vehicles and entering restrooms. For example, at most petrol stations, all passengers except the driver must exit the vehicle and wait outside a razor-wire fence. The driver must first show identification and offer the trunk for inspection before taking the vehicle to the pumps.

There is a general consensus among the online guides that north Xinjiang (north of the Tianshan Mountains 天山) has more natural beauty, while south Xinjiang (south of the Tianshan Mountains) has more interesting culture. Most guides start journeys in Urumqi, the capital and the only place where visitors can hire vehicles. One post on Mafengwo 马蜂窝 sums up the essential places to visit: "If you don't go to Xinjiang, you don't know how big China is. If you don't go to Ili (Yili 伊犁), you don't know how beautiful Xinjiang is. If you don't go to Kashgar, you haven't arrived in Xinjiang." 36 The last phrase echoes the tourist slogan of Kashgar, which is displayed prominently throughout the

35 “Xinjiang gaikuang” (Xinjiang general overview). Mafengwo, 11 August 2017, https://m.mafengwo.cn/ gl/catalog/index?id=776\&catalog_id=4050. Accessed 12 July 2019.

36 "Di yi ci qu Xinjiang, bi kan de xing qian shi da wenti quan jieda" (Ten essential question-and-answers for first-time visitors to Xinjiang). Mafengwo, 2018, http://www.mafengwo.cn/gonglve/ziyouxing/ 112050.html. Accessed 12 July 2019. 
city. For Han visitors, Kashgar is a city whose cultural bloodline links it to Aladdin and Afghanistan; some describe it as the least Chinese place in China. Tourists capture folk images of Uyghur pottery, fabrics, musical instruments, playful children and the wizened faces of old men. Yili features the alpine Lake Sayram (Sailimu hu 赛里木湖) and panoramic views of grasslands, providing tourists with the opportunity to photograph Kazakh herders tending to horses in green fields. Other well-travelled sites in Xinjiang include the Flaming Mountains (Huoyanshan 火焰山), the film location for the 1986 television serial Journey to the West, Bayanbulak grassland (Bayinbuluke 巴音布鲁克), Lake Kanas (Kanasi 喀纳斯) and the Pakistan border at Khunjerab Pass (Hongqilafu 红其拉甫).

As for routes, there are two roads commonly enjoyed for their unique scenery. The first is the Duku 独库 Highway, which connects Maytag (Dushanzi 独山子) and Kucha (Kuche 库车). Offering superb high-altitude views while crossing the Tianshan Mountains, tourists yield to herds of cattle and sheep, and park off-road to scrape ice off mountainsides and dip their feet in clear streams. On the way, many stop at the Qiaoerma 乔尔玛 Martyr's Monument. Memorializing the 168 members of the People's Liberation Army who sacrificed their lives to construct this roadway in the 1980s, the route has been heavily promoted by official and unofficial media as the "road of heroes" (yingxiong zhi lu 英雄之路).

The other "must-do" route traverses the Gobi Desert along Route 315. Nicknamed the "Tarim Desert Oil Road," it is considered to be a close analogue of segments of the ancient Silk Road. In this arid stretch, travellers typically get out of their cars to frolic among the sand dunes, rolling around, jumping and stomping in the sand. Alongside sand and water wells, the landscape is dominated by oil wells and the slogans of the China National Petroleum Corporation, which trumpet its extraordinary resilience in harsh conditions. One prominent sign popular with tourists snapping photographs reads: "Triumphing over a sea of death” (zhengzhan “siwang” zhi hai 征战“死亡”之海).

\section{Militarization and tourism}

Black uniforms, submachine guns, riot shields, facial scans and metal spikes feature in most tourist commentaries and are photographed frequently. Travellers arriving at the airport or train station in Urumqi are immediately confronted with People's Armed Police (wujing 武警). But whereas dread might be an assumed response, Chinese tourists instead feel reassured by the panoply of technologies and soldiers. Many travel diaries background their decision to enter Xinjiang with a debate between themselves and their anxious friends and relatives:

Many of my mainland (neidi 内地) friends will not dare go to Xinjiang, especially to the south, mainly because of safety concerns. In fact, there are many ethnic groups in Xinjiang, and Han are the majority. Various cities have a well instituted set of security personnel. Many Han 
Chinese have lived there for years. Terrorist attacks are quite rare, you are unlikely to be involved in one. ${ }^{37}$

This traveller situates himself in distinction from those who do not really know the facts.

The conventional wisdom about Xinjiang being an unwelcoming place is refuted by personal touring experience. Almost no diarists downplay the security apparatus as invisible or unremarkable; they see themselves as empirical validators who go into the field to relay on-the-ground truths back home and test common viewpoints:

I looked at travel logs and guides before and they said that Kashgar does not seem like a place in China, and the people there do not look Chinese. If we go to Kashgar, we would be treated like foreigners, and South Xinjiang is chaotic (luan 乱) and dangerous (weixian 危险), etc. Although this makes some sense, if you don't experience it personally, you can be mistaken. Actually, there is probably some danger, but many people live here. Will I really encounter riots at any time and place? ${ }^{38}$

A more patriotic testimonial also emphasizes the reassuring ubiquity of security institutions:

At Kargalik (Yecheng 叶城), the security check was especially strict. All the town entrances have armed police (wujing) and traffic police stops. Not only do you present your official identification, they inspect your luggage, and you have to open your hood; they inspect the interior of the vehicle and all your belongings. To enter lodgings, stores and restaurants, you have to go through a metal detector, get a simple frisk and open your bags ... People urged me to go past Yecheng straight to Kashgar, saying it wasn't safe. There was a recent revolt here. But I believe in the Party! I believe in the government! To exaggerate a little, every three steps is a guardpost (gang 岗), every five steps a sentry (shao 哨). People's armed police vehicles, traffic police vehicles and armoured cars are everywhere, really tight security ... It gives those trying to go about their everyday business a sense of security (anquangan 安全感). ${ }^{39}$

Another writer not only normalizes the policing but admires its comparative excellence in broader perspective:

Friends who want to go to Xinjiang worry about the safety issues. To this, let me say in all seriousness that Xinjiang has the best public security in all of China. It is said the amount of police in Xinjiang is greater than the total police force in the United States. I had heard before I left that it was chaotic, but after going it's no big deal ... I have been to many crime-filled cities, like Manila, Naples and Brussels, and so-called dirty cities like New York and Paris. Xinjiang is far above them. The streets are filled with police, with 24-hour patrols. The supermarkets, hotels, markets, buses, gas stations and ticketing halls all require ID and a security scan ... In any bad situation, you can find the police, who not only have a good attitude but are also handsome! 40

These narratives counter the commonly perceived risk of travelling in Xinjiang. They assert that the dangers are overstated; the people are not out to get you; there are large populations (especially of Han Chinese); the security levels ensure safe movement; and it is safer than many other areas of the world.

Securitization provides both a prior rationale for visiting and a post-hoc justification of their visit. It provides Chinese visitors with a dose of patriotic pride to

37 Tashkurgan (Tashikuergan 塔什库尔干), 2017.

38 Khunjerab, 2017.

39 Kashgar, 2017.

40 Tekes, 2018. 
see the region so safe and a sense of personal pride for relaying the message back home to others.

\section{Tourism as an ethnic classification project}

When travelling in Xinjiang, especially in south Xinjiang, tourists transition into spaces where Han Chinese are in the minority. Here, value is given to manageable degrees of difference, where tourist practices form public representations of membership and draw group boundaries. In general, tourists interacting with Uyghurs feel occasional unease, a tension which is less obvious in their interactions with Tajiks or Tibetans. I examine three modes of practice to show how tourism reflects ethnocultural distinction: mobility configurations, personal exchanges and intra-ethnic sharing.

Inequality in movement and space is integral to the political regime in Xinjiang. The activities of Han tourists make plain these disparities. One way is through their fear of sharing vehicles. For example, after landing at Kashgar airport, one visitor describes a feeling of “apprehensiveness” ( fachu 发怵) after being overwhelmed by a large number of bearded men offering taxi rides. ${ }^{41}$ Although some Han tourists occasionally pick up Tibetan hitchhikers, ${ }^{42}$ no diarists mention allowing Muslims in their vehicles, the main cited reason being the language barrier. One married couple state that they had a pre-existing policy to refuse hitchhikers but were nonetheless charmed by a Han soldier, whose combination of "gentle refinement, along with being Han, and having no barriers to communication" led them to shed their principles and offer him a ride. ${ }^{43}$ Pragmatic reasons are also given for the lack of cross-ethnic contact when travelling. As one rider explains, when sharing cars, police will conduct a more stringent inspection if Uyghurs are in the backseat. ${ }^{44}$

Although mobility restrictions such as having to present identification on the street, facial scans, security checkpoints, etc. are clearly aimed at Uyghurs, almost none of the mainland Chinese travel diaries makes overt reference to relative travel privilege. Compare this to one of the travellers from Taiwan, who acknowledges that Xinjiang is safe to travel through yet is struck by its disparities:

In fact, travelling in Xinjiang all this time you'll discover that the police and security personnel treat Han and Uyghurs very differently. Uyghurs will have to produce more documents and undergo deeper inspections. Whereas us Han, they will sometimes just quickly wave us through. ${ }^{45}$

It is probably no coincidence that the only mainland Chinese travelogue to mention separate standards was written by a gregarious family of three who met a

41 Yan'an 延安-Kashgar, 2017.

42 Lhasa-Namucuo 纳木错, 2014; Lhasa, 2016.

43 Tashkurgan, 2017.

44 Khotan (Hetian 和田), 2018.

45 Hami 哈密, 2018. 
pair of Uyghur students on the train to Urumqi. The students spoke fluent Mandarin and studied in the family's hometown. ${ }^{46}$ They even invited the Han family to their home to eat with them. A road trip by car inevitably will provide a more solitary experience and segregation than a journey by train, but it is the combination of personal openness, language parity and contact sites that likely explains such opportunities for fellowship.

Other opportunities for meaningful exchange are also constrained on vacations in Xinjiang. For instance, although there is a widespread custom for road travellers to deliver school supplies and clothing to needy schools in Tibetan regions, ${ }^{47}$ I found no evidence of such a practice in Xinjiang. This may not be entirely down to the tourists, who are unable to pass on anything hand-to-hand in Xinjiang. Many diaries point out how schoolyards in Xinjiang are tightly barricaded against public access. In contrast, road-trippers in Tibetan mountainous areas often cooperate directly with school administrators, driving along dirt roads to visit isolated elementary schools and handing out gifts personally, an informal charitable act not feasible in a context of militarization.

Reading the diary texts, it appears that none of the travellers added Uyghurs to their personal contacts in social networking applications. Compared with their interactions with Tibetans, they are less likely to use the inclusive term tongbao 同胞 (compatriots) to describe Uyghurs. Of the 22 Tibet travelogues, seven (32 per cent) use the term directly for Tibetans; of the 45 Xinjiang diaries, just three (7 per cent) do so for Uyghurs.

While some travellers to Tibet use phrasebooks and speak a few commonly used phrases, no tourists in Xinjiang attempt to tackle the language barriers. In areas of southern Xinjiang, many exchanges consist of just smiles, gestures, pointing and so forth. At times, such exchanges can feel one-sided as tourists, despite their unease, attempt to capture images of ethnic daily life through photography. Tourists in Tibet express sensitivity about wantonly snapping shots of pilgrims and monks, yet tourists in southern Xinjiang are even more circumspect, with multiple tourists envisioning scenarios of having to flee for their lives in old town Kashgar while taking pictures. ${ }^{48}$ Hinting at this concern, one man travelling with his wife and young daughter dispenses advice on how to win over the children in Kashgar:

If you want to engage with these children, it is simple. If you see a group of kids playing, you can sit down beside them and slowly work your way closer; this way they won't feel uneasy. You could put on a smile, take a photo for them, or hand them some snacks, to build good feelings. Children are all quite curious, especially about visitors, so it is easy to get close to them. ${ }^{49}$

A few travellers in old town Kashgar used black-and-white photography to capture images of local residents, adding a greater sense of social distance and otherness to even the mundane tourist practice of taking photographs. ${ }^{50}$

46 Kashgar-Altay (Aletai 阿勒泰), 2017.

47 Labrang Monastery 拉卜楞寺, 2015; Kashgar-Lhasa, 2017.

48 Aqsu (Akesu 阿克苏), 2015; Khunjerab, 2017.

49 Tashkurgan, 2017.

50 Kucha, 2017; Khunjerab, 2018. 
Tajiks elicit a more favourable response from Han tourists. One of the less populous ethnic minorities in China, Tajiks are heavily engaged in tourism. On the Pamir Plateau, tourists will often stay in yurts with a Tajik family or attend a Tajik wedding. The travelogues almost all describe Tajiks similarly - as pastoral, as surviving in demanding environments, as the only "white" ethnic minority in China and as being friendly towards the Chinese state. Travel sites note that Tajiks practise secularized Islam. Unlike Uyghurs, they are occasionally added to personal contacts. Thus, while contact sites and deep connections with Uyghurs seem limited, Tajik-Han relations appear to be brought closer through tourist practices.

It appears that travel in Xinjiang is also a reinforcer of intra-ethnic solidarity. One Taiwanese backpacker says openly what likely goes unstated by mainland Chinese:

We found a sedan driven by a [Xinjiang] Han to drive us ... They told us that seeking a car like we were was really dangerous. If a Uyghur picked us up, it would not be safe. Then, they proceeded to complain about how the Uyghurs made their everyday lives so inconvenient, why they had all the strict safety inspections. ${ }^{51}$

Here, local Han Chinese share their grievances about the "other" to perceived members of their own group.

Concurrently, tourists greatly cherish the sacrifices that (Han) soldiers made to open up and develop the region along the Duku Highway, near national borders at the Khunjerab Pass and Korgas (Huoerguosi 霍尔果斯) and in the oil industry. These infrastructural developments serve as symbolic achievements marking national strength. For example, signage in the First Oil Well scenic area and the Tamir Basin alludes to the tireless martyrdom of those working to develop Xinjiang. One tourist driving a sedan through southern Xinjiang exults in his diligent compatriots: "Building a road like this in an uninhabitable area is a magnificent feat; I'm amazed by the hardship endured by them, the engineering will and the strength (qiangda 强大) of the country." 52

Meanwhile, some tourists (although only a few go this far) insinuate themselves into national projects with subtle ways of identification. A father poetically alludes to the great Han explorer of the 2nd century BC: "In ancient times it was Zhang Qian 张寒 travelling to the west, now it is [father's name] travelling to Xinjiang." ${ }^{53}$ Near Bayanbulak Grassland, without a cell phone signal, another group connect their experience to that of their socialist predecessors:

[In the Gobi] on both sides, there are barren hills, with few plants growing, alongside broken, closed trains and half-cut mountain caves. We felt like those youth in the 1950s and 1960s sent down to Xinjiang to offer aid, a really unique feeling. ${ }^{54}$

Road-trip travellers incorporate tropes of bodily struggle and what Nelson Graburn calls "pioneer endurance." 55 This is enhanced by the sense of 
"extremity" that their travel in Xinjiang evokes: they experience extreme climates, at the extreme limits of Chinese territory, among extremely intrepid compatriots who have built roads and oil wells against extreme resistance.

\section{Authenticity and commercialization}

How do the massive spatial and socio-political changes in Xinjiang affect tourists' evaluation of their experience? As I have shown, the huge infrastructure projects and webs of surveillance have permitted increased consumption of landscapes and local culture by allowing feelings of safe mobility for Han Chinese tourists. Furthermore, the achievements and surveillance form part of the region's distinctiveness and make great social media content. Yet, connected to developmental policies are tourist concerns with authenticity. There are two side effects of state policy that tourists regard as antithetical to their desires: devitalized atmosphere and over-commercialization.

Han tourists are to some extent aware that minority populations are being moved around and that foot traffic is unusually low. They allude to Kazakh nomads leaving Chinese territory, the relocation of Uyghur residents and deserted markets. Some reviewers of Kashgar Old Town are underwhelmed by the lack of atmosphere caused by empty stalls and the absence of people.

In general, Han tourists in Xinjiang are not looking for a true backstage experience of ethnic life; they are content with what the frontstage can provide. They do not seek spiritual fulfilment from pure contact with opposing cultures, as so many theories of Western travel assume. ${ }^{56}$ If their middle-school textbook or the Xinjiang Museum says that an ethnic group wears X costume and eats $\mathrm{Y}$ food, they expect to witness or bodily engage with $\mathrm{X}$ and $\mathrm{Y}$. They are not like writer Edith Wharton touring Italy, fervently trying to detach her experience from Turner paintings. ${ }^{57}$ Rather, Han tourists in Xinjiang hope to attach themselves to the popular image. For example, when visiting the Flaming Mountains, they will generally take a picture next to the most symbolic image, the Monkey King statue. A site does not necessarily lose charm by having other tourists there; a certain number of visitors simply validates its common value. When touring cultural sites, they, like so many travellers, presume that what they see going on is an immobile social form that is always as they see it. ${ }^{58}$ There is no need for unmasking when no masking is presumed.

Even so, all else being equal, they prefer to experience different lifestyles with some depth and sincerity, for instance by staying in a Kazakh yurt to "understand the details (diyun 底蕴) of full-on grassland culture," 59 or circling a mosque to "genuinely experience (zhenzheng tiyan 真正体验) the lifeways of the local

59 Altay, 2017. 
ethnic minorities." 60 The adverb "genuinely" here implies there are lesser versions of experience. Similarly, Kashgar promotes itself as the only place where you are "genuinely" considered to be in Xinjiang.

Although a night of pre-arranged camping or circling a mosque might not qualify as true travel in Western middle-class eyes (as in the travel philosophy of Lonely Planet guides), it is enough to substantiate and validate many a journey for Han Chinese visitors. Moreover, elements of surprise - unplanned happenstances - loom large in these diaries. Having a vehicle stuck in the mud and then pushed out by several locals was a thrill for one couple in Wensu 温宿 Canyon. ${ }^{61}$ Another group took a wrong turn and ended up at a nuclear test research facility, where they excitedly paid homage to famous physicists. ${ }^{62}$

Many authors have explored how Chinese tourists differ from ideal typical Western ones in their different conceptions of authenticity, ${ }^{63}$ but few have analysed how Chinese tourists adamantly despise "commercialization" (shangyehua 商业化). For Chinese tourists, commercialization signifies the use of prefigured, procrustean styles of site management that detract from the native, unmediated and unfettered enjoyment of a place. It is not so much the idea of charging entrance fees that irks tourists, given that most attractions in China already require payments for access; rather, tourists resist the intensification of activities that centre on the pursuit of profit and that cover up local ecologies and cultures. ${ }^{64}$ In this, they can be said to follow the classical Marxian division between use value and exchange value. Where exchange values take over (as some believe has happened in Xinjiang tourism), the use values - the human needs that are supposedly fulfilled - become qualitatively diminished. In the case of tourism, this means that the ontological experience of the native, genuine destination is replaced by something that can only be mediated by money.

Characteristics of an over-commercialized site include fixed pathways, the inability to drive a car inside, high ticket prices, raised walkways for photo opportunities, charges for photographs and barricades around lakes. In Karamay (Kelamayi 克拉玛依), two male travellers in the scenic area of Black Oil Mountain (the supposed site of the first post-liberation oil well) are outraged at having to pay 40 yuan to see a hill and a black pool: "what was flowing here was not oil, but money." 65 Tourists disdain plastic, factitious, mercenary replicas of indigenous cultural items. At an exhibit in Turpan (Tulufan 吐鲁 番), one tourist group describes the replica Uyghur living spaces as somewhat fake, so they just took some pictures to prove they were there and left. ${ }^{66}$ Bazaars are only as good as the people in them, and places, such as Urumqi

60 Kashgar-Kazakhstan, 2016.

61 Tashkurgan, 2017.

62 Kucha-Kashgar, 2017.

63 Nyíri 2006; Shepherd 2009; Li, Sharpley and Gammon 2019.

64 Sun et al. 2019.

65 Karamay, 2016.

66 Lake Kanas, 2017. 
Market, receive negative reviews for being lifeless (lengqing 冷清) and lacking in popularity with locals. Conversely, the bazaar in Kucha is applauded for not being "overly opened for commercialization" and as a site where you can "see the folk customs in their original form." 67

Particularly with young tourists, scenery delights in inverse relation to the degree of management. A young female travelling in a group of five effuses about Lake Sayram's touristic immaturity:

Sayram gave me a feeling of "Wow!" I never expected a lake in the interior to be this clean, clear and free of impurities ... This is not some manmade, opened-up place, and it has no management and protection. Rocks and abandoned fishing nets sit randomly (suiyi 随意) on the lake shore. There is no jumble of things piled together, there is just the awe of seeing this lake that looks like an ocean. I don't want to stop looking. ${ }^{68}$

Because development spoils the organic scenery, some are thrilled at getting there before the aesthetic decline:

Even though the road now connects to the entrance of the Maytag Valley, right now it has not been commercialized. Other than a footbridge, there is no protection (weihu 维护). So, if you want to come, you should seize the day, because I feel in the future there will be many people. After commercialization, its sense of beauty will be impacted. ${ }^{69}$

Thus, although visiting a scenic site can provide an opportunity to tick something off a list, tourists still value the freedom to explore an organic place unsullied by money-making. Xinjiang tourism often fails to satisfy these preferences.

\section{Tourism and political legitimacy}

A final question is the extent to which tourists acquiesce in or endorse the package of policies governing Xinjiang. Construed broadly, tourism provides political legitimacy by naturalizing people's right to a certain geographic space through perception and bodily contact. Many diaries explicitly state that a visit to Xinjiang helps one to understand how "big" China is. Border gates are now almost guaranteed stops on trips to the region and help to confirm state geographical sovereignty. For example, the Kazakhstan border at Korgas displays a carved monument with a large map of China in relief, the islands claimed by China in the South China Sea sandwiched into the bottom-right corner. Tour groups gather together in front of the map, waving Chinese flags and singing the national anthem. ${ }^{70}$ As such, tourism in Xinjiang anoints the land into an enduring, integral whole known as China, the tourist body incorporating itself into this whole through personal perception and ritual.

Yet, there is certainly much cognitive dissonance with regard to the specific securitization policies in the region. With bodily security, there are countervailing forces of anxiety owing to the number of Uyghurs and assuagement given the

70 Korgas, 2017. 
number of soldiers. Although almost all travel diarists state explicitly that Xinjiang is safe, many construct phantom situations of dread, similar to the photography encounters outlined above. A young male travelling in a tour group through the alleyways of Kashgar has contradictory thoughts about his experience:

I thought that if a group of locals came charging in to extort me, there would literally be nothing I could do about it. But that clearly did not happen. In my mind the whole time I did not think anything dangerous would happen to me. Kashgar is such a charming city in the western region. ${ }^{71}$

This contrasts with the accounts of travellers in Tibet, who approve of the presence of security forces but rarely hint at any fear of violence or retribution. Freedom seems a fair trade to one diarist entering a night market in Xinjiang, who enjoys the advantages of confinement: "It felt like being in a cage. But from a visitor's perspective, it felt much safer." 72 In general, tourists present boldface taglines that state that Xinjiang is safe, but the fine print reveals their fear, unease and frustration.

Some tourists reveal an understated ambivalence about the securitization: the traveller who misses the bustling bazaars of yesteryear, the van driver annoyed at having to wait in long lines for petrol or the nature lovers who have their tripods seized at the train station. A few make oblique references to the absence of a critical mass of charming locals: "It's been said that because of security controls (zhian 治安), street markets (minjian jishi 民间集市) have been suppressed."73 The writer then immediately explains that Xinjiang is indeed safe, no matter what others say. Another notes that the Kazakhs have been fleeing China, which he hopes is simply a seasonal, pasture-related phenomenon. ${ }^{74}$ Thus, it is clear that tourists are cognizant of some drop in public cultural life in Xinjiang, but few acknowledge or will admit to the prejudicial treatment of Uyghurs in transportation and policing, nor to any type of forced relocation policies that depopulates the once alluring folk districts. Unfortunately for Uyghurs, Xinjiang is probably too replete in natural wonders (Sayram Lake, Duku Highway) and patriotic punctuations (border crossings, oil wells) to make preservation of authentic, spontaneous Islamic cultural life a sine qua non of its tourist industry.

\section{Conclusion}

Tourism has largely been overlooked in the story of state repression in Xinjiang since the late 2010s. Tourists visit Xinjiang for many reasons including its open landscapes, exotic cultures and ability to stoke feelings of adventure. Recent improvements in its infrastructure have also aided tourism and are indeed attractions in and of themselves.

74 Khunjerab, 2017. 
Tourism to Xinjiang cannot be separated from politics. The regional government looks to tourism as a source of both economic and symbolic capital, as a way to improve the investment climate, particularly as a cornerstone hub of the Belt and Road Initiative. For officials, increasing tallies of visitors prove the wisdom of stability maintenance policies, and for visitors, the stability maintenance policies prove the wisdom of their decision to journey there. Based on the travel diaries analysed here, I contend that tourists perform "rituals of reassurance" by correcting their social network's misapprehensions about its dangerous situation. ${ }^{75}$ At the western extremities, they learn "how big China is," venture off the beaten track, brave harsh terrain in SUVs, and implicate their own bodies in the grand project of controlling the contested spaces of the west by honouring soldiers and great explorers. The language of contact with Xinjiang's visual tableau orients visitors to the numerous sacrifices of the region's constructors, similar to how oil workers and long-term residents of Xinjiang are indoctrinated into the idioms of Han sacrifice. ${ }^{76}$

Here, tourists serve as information filters, personally resolving discrepancies and discordant elements through narrative. Xinjiang is certainly not an informational black hole. Whereas Uyghurs and Kazakhs find their positionings relentlessly monitored, and their cell phone photographs occasionally deleted by authorities, Han tourists are encouraged to circulate imagery, with the government even partnering with the live-streaming application Douyin to relay visitor impressions. ${ }^{77}$ As such, social media is used not to expose corruption or Party failures but to lend credence to Party propaganda - in this case to affirm a secure, well-ordered Xinjiang.

Certainly, online travel diarists are under pressure to self-censor their content and remove any language that might appear critical of the Party's narrative of Xinjiang's security and prosperity. While it is difficult to gauge the extent of the suppression of content, it must be said that diarists often furtively take pictures of military equipment, checkpoints and soldiers, all of which they acknowledge should not be done openly. They do not abide by principles of censorship in that regard. Furthermore, given that many writers offer effusive praise of the police and military, they are likely either sincere in their impressions or strategically signalling support for the government, or a combination of both. At least with the impressions of securitization, many tourists sidestep issues of repressive censorship to report on and openly express admiration for the situation in Xinjiang. However, it is more difficult to assess the sincerity of the opinions on issues of ethnic relations. Future research on travel writing in China will be needed to determine how self-censorship operates and shapes what impressions are shareable. 
Part of the repertoire of wonders, the state technostructure of control gains credence as another crowning national achievement. While a few travellers use their freedom of mediation to document specific surprising policing practices, these never counter the travellers' overarching presumption that securitization is improving the region. In fact, travellers evince an absolute trust in police and legal institutions in Xinjiang far and above what they would likely demonstrate in their home province. Hence, while most research on mobility and security concentrates on how negative images deter tourists, the data presented here show that tourists themselves actively perform impression management and reframe stigmatized destinations.

While any backstage ethnic performance is welcomed, there is little direct attempt to engage deeper with the militarization. Perhaps owing to selfcensorship, few mention the relative absence of adult males on the streets, and only one mainland Chinese notes the prejudicial segregation at security checkpoints. However, it is an overstatement to contend they are completely oblivious. One way to comment on the forced removal of conviviality is to call a place dull or lacking in popularity. Many of the travellers point out that people are being moved out and that the replacement - a type of renovated tourist zone - is generally unappealing to them.

Even though tourists proclaim the region to be safe, they still carry affective reactions of fear and anxiety when among Uyghurs, especially in comparison to their reactions to Tibetans. For sure, tourists treat Tibetans as timeless curiosities caught up in feudal religion and as unsophisticated but seemingly happy, in the way puppies might be considered happy. Yet, the Han tourists in Tibet often gift school supplies to local students, offer rides to Tibetan farmers, commend the spiritualized culture, admire the pilgrims, practise occasional Tibetan phrases and consider the Tibetans to be compatriots. In contrast, the data in this paper demonstrate that tourists in Xinjiang, especially when in the south, consider the local people to not look Chinese, not be safe to ride with and prone to sudden bursts of violence. These patterns of mobility and affective responses struggle to draw an inclusionary circle around Uyghurs based on anything other than their residence in Chinese-designated territory.

The developments in Xinjiang that do appal Han tourists involve the corruption of native charm and ecologies with fake, money-grubbing displays and the commercialized form of tourism beholden to "scenic area" models. To travellers, a line is crossed when a site that should be enjoyable-as-is becomes over-signified and over-commodified. While much tourism is still characterized by the visit-photograph-leave model, there is growing disenchantment, especially among road trippers, with the avariciousness of organized tourism. For Xinjiang's tourists, this frustration and resentment lies not so much with those who profit - tourism companies, locals and officials - as with how commercialization changes the encounter with the ecology and culture. Too much profiteering spoils the distinctive character of artifacts and events, or what Ning Wang 
calls "object-related authenticity."78 This analysis provides a corrective to the literature that regards Chinese tourists as unmoved by authenticity concerns and as mindless stampers of sites. ${ }^{79}$ They reprove the moats built around natural scenery, the transportation monopolies, the high entrance fees, the myriad demarcations and the forced beautifications. Ironically, the visitors here employ Marxian-style critiques of commodities long abandoned by the Communist Party. Thus, the space for political commentary is based on aesthetic taste, inscribed in the act of consumption. In Xinjiang, the state monopoly on force is welcome; the monopoly on beauty is not.

Tourists are liberal in what they consider to be genuine, but they do still expect a modicum of realism. Mainland tourists are remarkably unattuned to the inequalities in mobility and life chances: they are more concerned about being barricaded out (by entrance gates) than by the local peoples being barricaded in (by ethnic surveillance and mass incarceration). Their encounters with Muslims other than Tajiks are either fleeting or obstructed by transportation apartheid and a culture of fear. At present, meaningful relationships remain unattainable through tourism. Han tourists do not present personal gifts to Uyghurs and the everyday lives of Xinjiang residents are inaccessible to them.

In sum, Han tourists to Xinjiang believe that commercialization is unwarranted, but soldiers are not. With respect to the future of Xinjiang, ethnic policy aimed at Uyghurs, Hui and Kazakhs will likely only impact the sensibilities of Han Chinese tourists where it intersects with their antagonism towards tawdry profiteering.

\section{Acknowledgements}

I thank Tom Gold, Laura Enriquez, Nelson Graburn, Susan Xue and the reviewers for helpful comments at various stages of the project. Portions of this article benefited from feedback given by the Tourism Working Group and the Haas Junior Scholars Working Group at the University of California, Berkeley.

\section{Conflicts of interest}

None.

\section{Biographical note}

Gregory FAYARD is a $\mathrm{PhD}$ candidate in the department of sociology at the University of California, Berkeley. His current research looks at the importance of transportation and travel in China's modernization project, specifically how domestic and foreign travel are instrumental in forging a common belief system in the middle class and substantiating Chinese economic aid and investment. 


\begin{abstract}
摘要: 近年来, 进入中国新疆维吾尔自治区的国内旅游者呈现上升的趋 势。政府官员将旅游业视为经济资本的一个来源和社会稳定的助力。对他 们来说旅游业可能使得该地区显得次序井然，使其对未来的投资具有吸引 力。当前新疆旅游行业形势有两个矛盾之处。根据大多数文献, 大规模的 军事存在应当会使游客踌躇不前, 但实际上到访军事化的新疆的人数仍在 不断增加。另外, 新疆的一大吸引力是该地区的文化“异性”, 但这种文化 被国家针对伊斯兰的政策所压制。通过研究汉族游客在新疆旅行的网络游 记, 笔者分析新疆的游客体验如何肯定维持治安的合理性, 交通工具和人 际交往如何增强民族界限感, 以及政府政策如何影响中国旅行者对新疆认 识的真实度。尽管确保旅行者的人身安全能够佐证政策的政治合法性, 游 客还是反对景点景色官僚化的管理。因此大多数游客以审美品味为评价政 策的标准。
\end{abstract}

关键词: 新疆; 中国; 一带一路; 维吾尔族; 旅游

\title{
References
}

Airey, David, and King Chong. 2010. "National policy-makers for tourism in China." Annals of Tourism Research 37(2), 295-314.

Anderson, Amy, and Darren Byler. 2019. "Eating Hanness." China Perspectives 3(September), 17-26.

Byler, Darren. 2019. "Ghost world." Logic Magazine, 3 April, https://logicmag.io/07-ghost-world. Accessed 28 April 2019.

Chio, Jenny. 2014. A Landscape of Travel: The Work of Tourism in Rural Ethnic China. Seattle, WA: University of Washington Press.

Cliff, Tom. 2016. Oil and Water: Being Han in Xinjiang. Chicago, IL: University of Chicago Press.

Cockerell, Isobel. 2019. "Inside China's surveillance crackdown on Uyghurs.” Wired, 9 May, https:// www.wired.com/story/inside-chinas-massive-surveillance-operation. Accessed 15 June 2020.

Cohen, Erik, and Scott A. Cohen. 2012. "Current sociological theories and issues in tourism." Annals of Tourism Research 39(4), 2177-2202.

Decker, William Merrill. 2009. "Americans in Europe: Henry James to the present." In Alfred Bendixen and Judith Hamera (eds.), The Cambridge Companion to American Travel Writing. Cambridge: Cambridge University Press, 127-144.

Drakos, Konstantinos, and Ali M. Kutan. 2003. "Regional effects of terrorism on tourism in three Mediterranean countries." Journal of Conflict Resolution 47(5), 621-641.

Enders, Walter, and Todd Sandler. 1991. "Causality between transnational terrorism and tourism: the case of Spain." Terrorism 14(1), 49-58.

Finley, Joanne Smith. 2019. "Securitization, insecurity and conflict in contemporary Xinjiang: has PRC counter-terrorism evolved into state terror?" Central Asian Survey 38(1), 1-26.

Frank, Thomas. 1997. The Conquest of Cool: Business Culture, Counterculture, and the Rise of Hip Consumerism. Chicago, IL: University of Chicago Press.

Gorsuch, Anne E. 2003. “There's no place like home': Soviet tourism in late Stalinism." Slavic Review 62(4), 760-785.

Graburn, Nelson. 1977. "Tourism: the sacred journey.” In Valene Smith (ed.), Hosts and Guests: The Anthropology of Tourism. Philadelphia, PA: University of Pennsylvania Press, 17-31.

Hall, C. Michael, Dallen J. Timothy and David Timothy Duval. 2004. "Security and tourism: towards a new understanding?" Journal of Travel and Tourism Marketing 15(2-3), 1-18.

Jamison, David. 1999. "Tourism and ethnicity: the brotherhood of coconuts." Annals of Tourism Research 26(4), 944-967. 
Kolas, Ashild. 2008. Tourism and Tibetan Culture in Transition: A Place Called Shangrila. London: Routledge.

Leibold, James. 2020. "Surveillance in China's Xinjiang region: ethnic sorting, coercion, and inducement." Journal of Contemporary China 29(121), 46-60.

Lennon, J. John, and Malcolm Foley. 2000. Dark Tourism. London: Continuum.

Lepp, Andrew, and John Harris. 2008. “Tourism and national identity in Uganda." International Journal of Tourism Research 10(6), 525-536.

Li, Mohan, Richard Sharpley and Sean Gammon. 2019. "Towards an understanding of Chinese tourist photography: evidence from the UK." Current Issues in Tourism 22(5), 505-521.

Liu, Xin. 2019. "Tourism in Xinjiang booms thanks to social stability." Global Times, 21 January, http://www.globaltimes.cn/content/1136527.shtml. Accessed 25 October 2020.

Luo, Tianyi, and Bei Li. 2019. "Neirong fenxiangxing lüyou app yonghu chixu shiyong yanjiu - yi Mafengwo wei li" (Content analysis of travel sharing apps and research into consumer persistence in usage: the case of Mafengwo). E-Business Journal 3, 5-6.

Martin, Peter. 2019. “Inside Xinjiang: a 10-day tour of China's most repressed state.” Bloomberg, 24 January, https:/www.bloomberg.com/news/features/2019-01-24/inside-the-vast-police-state-at-theheart-of-china-s-belt-and-road. Accessed 18 May 2019.

Millward, James A. 1998. Beyond the Pass: Economy, Ethnicity, and Empire in Qing Central Asia, 1759-1864. Stanford, CA: Stanford University Press.

Mozur, Paul. 2019. "One month, 500,000 face scans: how China is using A.I. to profile a minority." New York Times, 14 April, https://www.nytimes.com/2019/04/14/technology/china-surveillanceartificial-intelligence-racial-profiling.html. Accessed 28 March 2020.

Nyíri, Pál. 2006. Scenic Spots: Chinese Tourism, the State, and Cultural Authority. Seattle, WA: University of Washington Press.

Oakes, Tim. 1997. "Ethnic tourism in rural Guizhou: sense of place and the commerce of authenticity." In Robert Everett Wood and Michel Picard (eds.), Tourism, Ethnicity, and the State in Asian and Pacific Societies. Honolulu, HI: University of Hawai'i, 35-70.

Perdue, Peter C. 2005. China Marches West: The Qing Conquest of Central Eurasia. Cambridge, MA: Belknap.

Phillips, Tom. 2017. "China orders hundreds of thousands of private cars to have GPS trackers installed for monitoring." The Guardian, 21 February, https://www.theguardian.com/world/2017/ feb/21/china-orders-gps-tracking-of-every-car-in-troubled-region. Accessed 25 October 2020.

Popp, Richard K. 2012. The Holiday Makers: Magazines, Advertising, and Mass Tourism in Postwar America. Baton Rouge, LA: Louisiana State University Press.

Pratt, Mary Louise. 2007. Imperial Eyes: Travel Writing and Transculturation. New York: Routledge.

Richter, Linda. 1980. "The political uses of tourism: a Philippine case study." The Journal of Developing Areas 14(2), 237-257.

Rivera, Lauren A. 2008. "Managing 'spoiled' national identity: war, tourism, and memory in Croatia." American Sociological Review 73(4), 613-634.

Saha, Shrabani, and Ghialy Yap. 2014. "The moderation effects of political instability and terrorism on tourism development: a cross-country panel analysis.” Journal of Travel Research 53(4), 509-521.

Salazar, Noel B. 2012. "Tourism imaginaries: a conceptual approach." Annals of Tourism Research 39(2), 863-882.

Sanchez, Peter M., and Kathleen M. Adams. 2008. "The janus-faced character of tourism in Cuba." Annals of Tourism Research 35(1), 27-46.

Shepherd, Robert. 2009. "Cultural preservation, tourism and 'donkey travel' on China's frontier." In Tim Winter, Peggy Teo and T.C. Chang (eds.), Asia on Tour: Exploring the Rise of Asian Tourism. London: Routledge, 253-263.

Standish, Reid, and Aigerim Toleukhanova. 2019. "Kazakhs won't be silenced on China's internment camps.” Foreign Policy (blog), 4 March, https:/foreignpolicy.com/2019/03/04/961387-concentrationcampschina-xinjiang-internment-kazakh-muslim. Accessed 18 June 2020. 
Sun, Xiaolong, Bishu Lin, Yonghong Chen, Shuyin Tseng and Jie Gao. 2019. "Can commercialization reduce tourists' experience quality? Evidence from Xijiang Miao village in Guizhou, China." Journal of Hospitality and Tourism Research 43(1), 120-140.

Thum, Rian. 2018. "China's mass internment camps have no clear end in sight." Foreign Policy (blog), 22 August, https://foreignpolicy.com/2018/08/22/chinas-mass-internment-camps-have-noclear-end-in-sight. Accessed 7 September 2018.

Vanderklippe, Nathan. 2018. "It is about Xi as the leader of the world': former detainees recount abuse in Chinese re-education centres." The Globe and Mail, 3 July, https://www.theglobeandmail.com/ world/article-former-detainees-recount-abuse-in-chinese-re-education-centres. Accessed 18 July 2018.

Wang, Ning. 1999. "Rethinking authenticity in tourism experience." Annals of Tourism Research 26(2), 349-370.

Wang, Zhida. 2014. "Xinjiang lüyouju juzhang: jiangli mei wei dao Xinjiang de youke 500 yuan" (Director of Xinjiang Tourism Bureau: every visitor to Xinjiang gets 500 yuan). People's Daily, 28 May, http://hn.people.com.cn/BIG5/n/2014/0528/c338398-21300484.html. Accessed 25 October 2020.

Wood, Robert E. 1984. "Ethnic tourism, the state, and cultural change in Southeast Asia." Annals of Tourism Research 11(3), 353-374.

Wu, Mao-Ying, and Philip L. Pearce. 2016. "Tourism blogging motivations: why do Chinese tourists create little 'Lonely Planets'?" Journal of Travel Research 55(4), 537-549.

Xu, Chang. 2018. "Shehui anquan wending zhutui Xinjiang lüyou da fazhan" (Social safety and stability boosts Xinjiang tourism development). Guangming Daily, 14 March, http://epaper.gmw.cn/ gmrb/htm1/2018-03/14/nw.D110000gmrb_20180314_3-11.htm. Accessed 22 March 2020.

Zenz, Adrian. 2018a. "China's domestic security spending: an analysis of available data." The Jamestown Foundation, March, https://jamestown.org/program/chinas-domestic-security-spending-analysisavailable-data. Accessed 5 August 2019.

Zenz, Adrian. 2018b. "'Thoroughly reforming them towards a healthy heart attitude': China's political re-education campaign in Xinjiang." Central Asian Survey 38(1), 1-27.

Zenz, Adrian. 2019. "Brainwashing, police guards and coercive internment: evidence from Chinese government documents about the nature and extent of Xinjiang's 'vocational training internment camps'." Journal of Political Risk 7(7), https://www.jpolrisk.com/brainwashing-police-guards-andcoercive-internment-evidence-from-chinese-government-documents-about-the-nature-and-extent-ofxinjiangs-vocational-training-internment-camps. Accessed 11 July 2019. 